ks. Jan Nowak

\title{
Podstawy „wyobraźni miłosierdzia” w nauczaniu Ojca Świętego Jana Pawła II
}

Charakterystyczna dla pontyfikatu Jana Pawła II jest troska o człowieka i jego godność. Od początku swego pontyfikatu papież zwracał uwagę na człowieka cierpiącego i najuboższego. Zauważając coraz większe obszary nędzy materialnej i duchowej współczesnego człowieka wzywał do miłosierdzia. Bóg bogaty $w$ miłosierdzie to nie tylko tytuł encykliki, ale temat wielu przemówień Ojca Świętego. W tym artykule podejmujemy temat wyobraźni miłosierdzia, która skupia uwagę na twórczej i czynnej miłości wobec cierpiącego człowieka. Zanim jednak to uczynimy, winniśmy rozważyć tajemnicę Bożego miłosierdzia na podstawie encykliki Dives in misericordia. Boże miłosierdzie jest podstawą dla wyobraźni miłosierdzia i z niego wypływają jej fundamentalne zasady.

Wyrażenie „wyobraźnia miłosierdzia” omówione zostało w liście apostolskim Novo millenio ineunte. Ojciec Święty podkreślił jej rolę w życiu błogosławionych i świętych w kazaniu wygłoszonym na Błoniach krakowskich w roku 2002. Źródłem dla wyobraźni miłosierdzia jest miłość Boga, która w osobie Jezusa Chrystusa zbliżyła się do człowieka, nadając nie tylko sens jego życiu, ale i każdemu czynowi. W ten sposób miłosierdzie Boga jest fundamentem dla miłosierdzia wobec bliźniego.

Biblijna wizja miłosierdzia Bożego w encyklice Dives in misericordia

BÓG BOGATY W MIŁOSIERDZIE

Encyklika Dives in misericordia zaczyna się od słów: „Bogaty w miłosierdziu swoim Bóg” (por. Ef 2, 4). Jan Paweł II już na początku podkreśla, że objawienie Boże ukazuje nam ucznia, który prosi Jezusa: „Panie, pokaż nam Ojca”. Na co Jezus odpowiada: „Kto Mnie zobaczył, zobaczył także i Ojca” (J 14, 9). W Jezusie Chrystusie widzimy oblicze Ojca. Chociaż Boga można poznać przez Jego dzieła, to jednak pełny obraz Ojca widzimy w Jezusie. Tylko Chrystus o Nim w pełni poucza (por. J 1, 18). Chrystus przyszedł na ziemię, aby 
tę prawdę objawić człowiekowi potrzebującemu. Ojciec Święty tak tłumaczy potrzeby cierpiącego człowieka: ,Znamienne, że tymi ludźmi są nade wszystko ubodzy, nie mający środków do życia, są ludzie, których pozbawiono wolności, są ślepi, którzy nie widzą całego piękna stworzenia, są ci, którzy żyją w ucisku serca lub też doznają społecznej niesprawiedliwości, są wreszcie grzesznicy. Wobec tych nade wszystko ludzi Mesjasz staje się szczególnie przejrzystym znakiem Boga, który jest miłością, staje się znakiem Ojca"1.

W Nowym Testamencie obraz kochającego Ojca ukazany jest szczególnie w przypowieściach o synu marnotrawnym, zagubionej owcy i drachmie, miłosiernym Samarytaninie, niemiłosiernym słudze oraz w alegorii o dobrym pasterzu. Wszystkie te teksty ukazują bogactwo miłosierdzia Bożego i napełniając treścią wyobraźnię, chcą pobudzić do refleksji i czynnej miłości miłosiernej². Owa czynna miłość ma się objawić w wypełnieniu przykazania miłości, a zwłaszcza życia błogosławieństwem: „Błogosławieni miłosierni, albowiem oni miłosierdzia dostąpią" (Mt 5, 7). W ten sposób możemy przybliżyć obraz Bożego miłosierdzia ukazany w słowach i czynach Jezusa.

\section{Stary Testament o Bożym MiŁosierdziU}

Jezus mówił do ludzi Starego Przymierza, „którzy nie tylko znali pojęcie miłosierdzia, ale którzy ponadto ze swej wielowiekowej historii, jako Lud Boży Starego Przymierza wynieśli szczególne doświadczenie miłosierdzia Bożego. Było to doświadczenie zarówno społeczne i wspólnotowe, jak też indywidualne i wewnętrzne" ${ }^{3}$. Ks. Jerzy Chmiel, zwracając uwagę na ten słowa w komentarzu do encykliki, stwierdził, że „teksty biblijne Starego Testamentu mówią nam o:

$1^{\circ}$ miłosierdziu Boga względem narodu, z którym zawarł przymierze,

$2^{\circ}$ względem poszczególnych ludzi grzesznych i słabych,

$3^{\circ}$ dlatego też sam Bóg jest miłosierdziem i

$4^{\circ}$ wymaga od człowieka, aby naśladował miłosierdzie Stwórcy.

Te cztery komponenty miłosierdzia Starego Testamentu możemy obserwować w poszczególnych fazach rozwoju tradycji biblijnej"4. Fakty te kierują naszą uwagę w stronę Boga, który jest miłosierny. W Starym Testamencie istota miłosierdzia zawarta jest w przymierzu, które Bóg zawiera z Mojżeszem, jako „Bóg miłosierny i litościwy, cierpliwy, bogaty w łaskę i wierność” (Wj 34, 6).

${ }^{1}$ JAN PaWeE II, enc. Dives in misericordia, 3.

${ }^{2}$ Por. tamże.

${ }^{3}$ Tamże, 4.

${ }^{4}$ J. ChMiel, Starotestamentalna semantyka mitosierdzia w encyklice Dives in misericordia, [w:] Encyklika Ojca Świętego Jana Pawła II o Bożym miłosierdziu Dives in misericordia. Tekst i komentarz, [Kraków 1981], s. 79. 
Określenia te są świadectwem doświadczenia miłosierdzia Bożego ludu Starego Przymierza, które zawarte jest w słownictwie używanym wówczas na określenie miłosierdzia. Szczególnie ważne są trzy określenia. Pierwsze hesed oznacza dobroć Boga oraz wierność przymierzu. Mimo że naród był niewierny, Bóg był wierny. Drugie określenie rahamim wskazuje na miłość matczyną, pełną tkliwości, cierpliwości, dobroci, wyrozumiałości i gotowości przebaczenia. Trzecie hanan oznacza wielkoduszne usposobienie, życzliwe i łaskawe. Oprócz tych zasadniczych wyrazów są zaznaczone także inne: hamal oznaczający litość i współczucie wobec pokonanego wroga, któremu się prze-

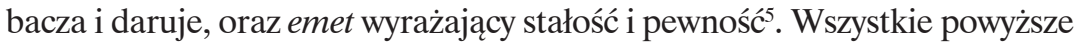
terminy ukazują odcienie miłosierdzia, wskazując na bogactwo treści. Ukazują one Boga miłosierdzia, który jest nie tylko dobry i wierny, ale cierpliwy, wyrozumiały, wielkoduszny, życzliwy i łaskawy, współczujący i przebaczający. Na takiego Boga Miłosierdzia można zawsze liczyć. On jest stały i pewny w swym miłosierdziu. Biblia grecka tłumaczy wszystkie te wyrazy hebrajskie słowami eleos i eleein. Ks. Jerzy Chmiel podkreśla, że one przygotowują drogę do chrześcijańskiej miłości (agape ${ }^{6}$. Także ks. Stanisław Hałas pochyla się nad tym zagadnieniem ${ }^{7}$. Wierność i dobroć Boga w Starym Testamencie domagały się zwykłej sprawiedliwości, czyli dochowania wierności Bogu ze strony ludu. Naród wybrany często był niewierny i dlatego miłość miłosierna była większa niż sprawiedliwość. Jan Paweł II tak mówi o niej: „Jest większa w tym znaczeniu, że jest pierwsza i bardziej podstawowa. Miłość niejako warunkuje sprawiedliwość, a sprawiedliwość ostatecznie służy miłości”». Ks. Józef Homerski podkreśla, że „Bóg w swej sprawiedliwej miłości stanowiącej Jego istotę przychodzi człowiekowi zawsze z pomocą. [...] Sprawiedliwość służy miłości, a ta z kolei objawia się w miłosierdziu". Dlatego miłosierdzie opiera się na sprawiedliwości i prowadzi do miłości.

${ }^{5}$ Por. JAN PAWEe II, enc. Dives in misericordia, 4.

${ }^{6}$ Por. J. Chmiel, Starotestamentalna semantyka miłosierdzia..., art. cyt., s. 77-78.

${ }^{7}$ S. HaŁas, Bóg jako Ojciec miłosierny. Biblijne podstawy teologii miłosierdzia, „Sympozjum” 2 (2003), s. 48: „W księgach Starego Testamentu dominuje przede wszystkim motyw miłosierdzia Bożego. Właśnie Bóg Jahwe jest wiele razy nazwany «miłosiernym», i to przy użyciu kilku różnych określeń. Często są one ułożone w pewną, bardzo charakterystyczną konstrukcję literacką. Wygląda ona w swej zasadniczej formie tak:

El hannun - Bóg łaskawy,

werahum - i miłosierny

erek afaim - nieskory do gniewu

we rab hesed - i wielkiej dobroci".

${ }^{8}$ JAN PAWEt II, enc. Dives in misericordia, 4.

${ }^{9}$ J. Homerski, Sprawiedliwość - miłość - miłosierdzie (refleksje biblijne nad III rozdz. encykliki: Dives in misericordia), [w:] Encyklika Ojca Świętego Jana Pawła II o Bożym miłosierdziu..., dz. cyt., s. 93. 


\section{ObraZ Milosierdzia w Nowym Testamencie}

Boga bogatego w miłosierdzie Jezus ukazał w przypowieści o synu marnotrawnym. Tenże syn opuścił dom ojca i utracił dobra, które otrzymał w spadku. W końcu zobaczył swoją nędzę i uświadomił sobie, że może powrócić do domu ojca tylko na prawach najemnika - chce sprawiedliwości. Tymczasem ojciec okazuje miłość, która staje się miłosierdziem, gdy przekracza „ścisłą miarę sprawiedliwości” ${ }^{10}$. Otrzymuje z miłosierdzia ojca godność syna i wszystko, co tej godności przypada. Ojciec okazał się wierny sobie, swojej miłości i dlatego przyjął go do domu z radością i szczodrobliwością budzącą zazdrość u brata. Wierny i czuły ojciec ocala człowieczeństwo syna, ocala jego godność, a znakiem tego jest wielka radość i wesele wydane na cześć marnotrawnego syna. Ojciec święty podsumowuje tę przypowieść słowami: miłość miłosierna „zdolna jest do pochylenia się nad każdym synem marnotrawnym, nad każdą ludzką nędzą, nade wszystko zaś nad nędzą moralną, nad grzechem. Kiedy zaś to czyni, ów, który doznaje miłosierdzia, nie czuje się poniżony, ale odnaleziony i «dowartościowany»"11. Radość z nawrócenia i zamieszkania w domu ojca na prawach syna podkreśla, jakim skarbem jest człowiek i jego godność, mimo całej prawdy o słabości i grzechu. Miłosierdzie to odkrycie, że jesteśmy bezcenni dla Boga, mimo że za grzech należy się sprawiedliwa kara. Bóg nie skupia się na karze, ale na godności i wielkości człowieka, dla którego posłał na świat Syna, a Ten dla niego umarł i zmartwychwstał.

Szczyt miłosierdzia. „Misterium paschalne stanowi szczytowy punkt tego właśnie objawienia i urzeczywistnienia miłosierdzia, które jest zdolne usprawiedliwić człowieka, przywrócić sprawiedliwość w znaczeniu owego zbawczego ładu, jaki Bóg od początku zamierzył w człowieku, a przez człowieka w świecie" 12 . Misterium paschalne kosztowało Chrystusa cierpienie w Ogrójcu, wyszydzenie, skazanie, ubiczowanie, cierniem koronowanie, przybicie do krzyża. Wówczas potrzebował On pomocy, a został opuszczony i w tej sytuacji najbardziej pomógł człowiekowi przez krzyż. Owocem krzyża jest łaska miłosierdzia, która doprowadza do nowego przymierza, przymierza miłości. Ten krzyż mówi o Bogu wiernym, który tak „umiłował świat, że Syna swego Jednorodzonego dał, aby każdy, kto w Niego wierzy, nie zginął, ale miał życie wieczne" (J 3, 16). Ukrzyżowany ukazuje, że miłość jest potężniejsza od zła. „Uwierzyć zaś w taką miłość to znaczy uwierzyć w miłosierdzie. Miłosierdzie jest bowiem [...] jakby drugim jej imieniem"13.

\footnotetext{
${ }^{10} \mathrm{~J}$ AN PAwEe II, enc. Dives in misericordia, 5.

11 Tamże, 6.

12 Tamże, 7.

${ }^{13}$ Tamże.
} 
Miłość potężniejsza niż śmierć i grzech. Biblia mówi, że Jezus w swej miłości był posłuszny aż do śmierci (por. Flp 2, 8). Został zniszczony przez grzech, którego nie popełnił, ale wykupił grzesznika i dokonał usprawiedliwienia, uwolnił z grzechu wypełniając misję miłosierdzia. W ten sposób ukazał program miłosierdzia dla Kościoła. Jest to program krzyża. Ukrzyżowany pobudza do miłosierdzia i chce wyzwolić w nas miłość. Wypełniając to wezwanie stajemy się błogosławieni. „W swoim zmartwychwstaniu Chrystus objawit Boga miłości miłosiernej właśnie przez to, że jako drogę do zmartwychwstania przyjął krzyż” ${ }^{14}$. Zmartwychwstanie ukazuje, że miłość jest potężniejsza niż śmierć.

Matka miłosierdzia. Maryja głosiła miłosierdzie, czego świadectwem jest nawiedzenie krewnej Elżbiety i modlitwa Magnificat (zob. Łk 1, 50). Odkryła miłość i ofiarę związaną z ofiarą Syna. Ona znała tajemnicę Bożego miłosierdzia, której doświadczyła pod krzyżem. W ten sposób przybliżała nam miłosierdzie Boże (por. J 19, 25-27). Matka jest wrażliwa i ma szczególną zdolność docierania do wszystkich potrzebujących i wstawiania się u Ojca przez Jezusa.

Rola Kościoła. Obraz miłosierdzia Bożego ukazany jest w Chrystusie. „Kto Mnie zobaczył, zobaczył także i Ojca” - mówi Chrystus (J 14, 9). Dzieło Jezusowego miłosierdzia możemy „zobaczyć” i przyjąć w Kościele przez sakramenty, zwłaszcza pokuty i Eucharystii. W sakramencie pokuty doznajemy miłości przebaczającej, która wzywa nas do pokuty i przebaczenia (por. Mt 5, 23-26). Przebaczenie w Kościele jest widoczne w życzliwej, pełnej czułości trosce rodziców i najbliższych. W parafiach i we wspólnotach najlepiej widoczny jest skarb miłosierdzia we wzajemnej trosce, przebaczeniu i jedności.

Jan Paweł II chce, aby miłość miłosierna była podstawą dla wyobraźni miłosierdzia. Aby to się dokonało, należy ukazać najważniejsze zasady wpisane w encyklikę Dives in misericordia, którymi winni się kierować ci, chcący pomóc cierpiącym i najuboższym.

\section{Fundamentalne zasady „wyobraźni miłosierdzia”}

w encyklice Dives in misericordia

Objawienie miłości Ojca, który jest bogaty w miłosierdzie, dokonuje się przez Jezusa Chrystusa. W Chrystusie można zobaczyć, kim jest człowiek i jakie są jego potrzeby. „Człowiek i jego najwyższe powołanie odsłania się w Chrystusie poprzez objawienie tajemnicy Ojca i Jego miłości" ${ }^{15}$. Chrystus przychodzi z miłością i ogarnia całe człowieczeństwo. W tym mieści się pierwsza fundamentalna zasada miłosierdzia.

\footnotetext{
14 Tamże, 8.

15 Tamże, 1.
} 
Druga zasada wskazuje na miłosierdzie w Biblii. W Starym Testamencie Bóg miłosierny zawarł przymierze z ludem i był wierny temu przymierzu, wychowując naród do wymagającej odpowiedzi na to miłosierdzie. W Nowym Testamencie Chrystus na podstawie przypowieści o synu marnotrawnym ukazuje utratę godności człowieka. Wracający syn nie ma poczucia, że miłosierdzie ojca poniża go i uwłacza jego godności, lecz doświadcza wspólnie z ojcem, czym jest godność człowieka i dzięki temu staje w całej prawdzie. „Tym jaśniej widać, iż miłość staje się miłosierdziem wówczas, gdy wypada jej przekroczyć ścisłą miarę sprawiedliwości”"16. Miarą sprawiedliwości byłoby to, że syn staje w gronie sług i niewolników. Miłosierdzie czyni go synem. Ojciec ,,jak gdyby zapomina o całym złu, którego przedtem dopuścił się syn”17. Fundamentalną zasadą jest miłosierna troska Boga o to, by ocalić godność człowieka, pomóc się mu odnaleźć i żyć w braterstwie i wspólnocie.

Kolejną zasadą jest Boże miłosierdzie ukazane w krzyżu. Krzyż przede wszystkim jest pełną sprawiedliwością, którą zapłacił Jezus za grzech człowieka, ale nade wszystko krzyż jest objawieniem miłosierdzia w trosce o człowieka. Krzyż ukazuje prawdę, że Bóg zbliżył się do człowieka cierpiącego, bo sam cierpiał. Stał się przez to bliźnim i solidarnym z człowiekiem. W ten sposób krzyż zawiera program sprawiedliwości i miłosierdzia.

Następna zasada miłosierdzia wskazuje na Matkę Chrystusa. Ciągle staje przed nami obraz Matki Bożej, która doświadczyła miłosierdzia i przychodzi z miłosierdziem do tych, którzy cierpią, do ubogich, więźniów, uciśnionych, grzeszników. Zetknięcie się ze złem, moralnym i fizycznym, w ludzkich sercach było dla Matki Bożej wezwaniem, by wskazywać na Chrystusa ukrzyżowanego i zmartwychwstałego, który jest uzdrowieniem i uwolnieniem.

Twórczość człowieka, panowanie nad przyrodą, możliwości rozwoju i postępu są cennym bogactwem, ale też mogą doprowadzić do pychy i niewiary. Rezultatem takiego podejścia może być prymat rzeczy nad osobą, techniki nad osobą, mieć nad być. To z kolei prowadzi do tego, że osoba ludzka nie liczy się, a liczy się tylko ekonomia, gospodarka, a w imię sprawiedliwości odrzuca się elementarne prawa osoby. Konsekwencją tego jest terroryzm i okrucieństwo, brak sensu życia i poszanowania życia, rozpad rodziny. „Kościót podziela niepokój tylu wspótczesnych ludzi. Musi poza tym niepokoić upadek wielu podstawowych wartości, które stanowią niewątpliwe dobro nie tylko chrześcijańskiej, ale po prostu ludzkiej moralności, kultury moralnej - takich, jak poszanowanie dla życia ludzkiego, i to już od chwili poczęcia, poszanowanie dla małżeństwa w jego jedności nierozerwalnej, dla stałości rodziny" ${ }^{18}$. Nie tylko mamy troszczyć

\footnotetext{
16 Tamże, 5.

17 Tamże.

${ }^{18}$ Tamże, 12.
} 
się o wartości, ale też uczyć innych, by odpowiadali swoim życiem na wartości im ukazywane. Inaczej mówiąc - nie tylko miłosierdzie dawać, lecz umieć przyjmować miłosierdzie. Dzieląc się dobrem otrzymujemy w zamian dobro. „Jeśli tej dwustronności, tej wzajemności brak, wówczas czyny nasze nie są jeszcze prawdziwymi aktami miłosierdzia"19. Dlatego konieczna jest zasada świadectwa miłosierdzia zarówno w słowach, jak i w czynach.

Ogromnie ważną zasadą jest przebaczenie. Papież ukazuje ewangelię przebaczenia jako ewangelię miłosierdzia. „Błogosławieni miłosierni, albowiem oni miłosierdzia dostąpią" (Mt 5, 7). Szczęśliwy, który przebacza, bo sam otrzyma przebaczenie Ojca. Żyjąc tym przebaczeniem, możemy nie tylko zjednoczyć się z Jezusem, ale doświadczyć przebaczenia Ojca.

Na koniec ważne są dwie zasady, które przypomina Kościół. Jedna z nich mówi o tym, że miłosierdzie Boże udzielane jest w sakramentach, zwłaszcza w sakramencie pokuty i Eucharystii. Następna dotyczy modlitwy. Kościół wzywa wszystkich do wielkiego wołania w modlitwie o miłosierdzie Boga. Wszystkie powyższe zasady przeżywane w duchu wiary, nadziei i miłości pomogą wypracować w sobie wyobraźnię miłosierdzia.

\section{„Wyobraźnia miłosierdzia” w liście apostolskim}

\section{Novo millenio ineunte}

Jan Paweł II jeden z punktów rozdziału czwartego listu apostolskiego Novo millenio ineunte pt. Świadkowie miłości poświecił miłosierdziu. Zanim podejmiemy się analizy wyrażenia „wyobraźnia miłosierdzia”, należy podkreślić, że Ojciec Święty zwrócił uwagę na podejmowanie dzieł miłosierdzia, które określają „kształt życia chrześcijańskiego, styl działalności kościelnej i treść programów duszpasterskich"20. Papież zwraca uwagę na wieloraką pomoc cierpiącym. Potrzebują pomocy ci, którym brak podstawowych warunków do godnego życia. $\mathrm{Ci}$, „którzy umierają z głodu, skazani na analfabetyzm, nie mający dostępu do najbardziej podstawowej opieki lekarskiej, pozbawieni domu”21. Zagraża im „rozpacz płynąca z poczucia bezsensu życia, niebezpieczeństwo narkomanii, opuszczenie w starości i chorobie, degradacja lub dyskryminacja społeczna"22. Wobec takich niebezpieczeństw nie tylko potrzeba litościwej miłości, ale twórczej inicjatywy.

Czyny miłosierdzia będą możliwe, jeśli na świecie nie braknie ducha poświęcenia wobec najuboższych. Źródłem zaś i motywem tych czynów winien

\footnotetext{
19 Tamże, 14.

${ }^{20} \mathrm{~J}$ AN PAWEE II, list apost. Novo millenio ineunte, 49.

${ }^{21}$ Tamże, 50.

${ }^{22}$ Tamże.
} 
być dla chrześcijanina Chrystus, którego oblicze zobaczy w ubogich i cierpiących $^{23}$. Dlatego pierwsze zadanie to zobaczyć Jezusa, a przez to dostrzec prawdziwe potrzeby oraz zauważyć miejsca, w których panuje bieda i cierpienie. Z takiej wiary może dopiero wynikać dzieło miłosierdzia. Następnym zadaniem jest głoszenie, czyli ewangelizowanie, aby każdy mógł spojrzeć z wiarą na najuboższych i przez to spełnić miłosierdzie ewangeliczne. Dlatego też najpierw trzeba zobaczyć Chrystusa i uwierzyć w Niego, następnie wejść we wspólnotę Kościoła, w której spełnia się dzieło miłosierdzia, a wreszcie wypełnić posłanie Chrystusa: Idźcie i głoście miłosierdzie.

Wobec takiej perspektywy możemy postawić pytanie: czym jest wyobraźnia miłosierdzia i co to znaczy mieć wyobraźnię miłosierdzia? Ojciec Święty tak odpowiada nam na to pytanie: „Potrzebna jest dziś nowa «wyobraźnia miłosierdzia», której przejawem będzie nie tyle i nie tylko skuteczność pomocy, ale zdolność bycia bliźnim dla cierpiącego człowieka, solidaryzowania się z nim, tak aby gest pomocy nie był odczuwany jako poniżająca jałmużna, ale jako świadectwo braterskiej wspólnoty dóbr”24.

Główny akcent Jan Paweł II położył na zdolności bycia bliźnim, bycia bratem i stworzenia środowiska, gdzie będzie pielęgnowana zdolność bycia bliźnim dla cierpiącego człowieka, solidaryzowania się z nim. Taka zdolność jest potrzebna, by cierpiący poczuł się dobrze w braterskiej wspólnocie.

Papież zwraca uwagę nie tyle na skuteczność działania, ile na solidarność. Chodzi o to, by umieć razem nieść trudy życia, by stać się ubogim dla ubogich, by nikt nie czuł się przybity, zrozpaczony, bezdomny, lecz doświadczył życzliwości i wprost domowej atmosfery. Dlatego konieczne są postawy, o których poucza słowo Boże. Już w Starym Testamencie jest mowa o Bogu, który jest litościwy, cierpliwy, łagodny, dobry. Bóg przymierza jest wierny i stały. Te wszystkie wartości są według Ojca Świętego ukazane przez Chrystusa. „Duch Pański spoczywa na Mnie, ponieważ Mnie namaścił i posłał Mnie, abym ubogim niósł dobrą nowinę, więźniom głosił wolność, a niewidomym przejrzenie; abym uciśnionych odsyłał wolnymi, abym obwoływał rok łaski od Pana” (Łk 4, 18-19).

Ojciec Święty wskazuje Kościołowi „opcję preferencyjną” wobec ubogich $^{25}$. Miłość Jezusa, która jest miłosierna, ukazuje Kościołowi prawdziwe potrzeby bliźniego. Kościół daje świadectwo miłości, wychodząc naprzeciw

${ }^{23}$ „Jeśli nasze działania rzeczywiście mają początek w kontemplacji Chrystusa, to powinniśmy umieć Go dostrzegać przede wszystkim w twarzach tych, z którymi On sam zechciał się utożsamić: «Bo byłem głodny, a daliście Mi jeść; byłem spragniony, a daliście Mi pić; byłem przybyszem, a przyjęliście Mnie; byłem nagi, a przyodzialiście Mnie; byłem chory, a odwiedziliście Mnie; byłem w więzieniu, a przyszliście do Mnie» (Mt 25, 35-36) - tamże, 49.

${ }^{24}$ Tamże, 50.

${ }^{25}$ Por. tamże, 49. 
tym, którzy są w potrzebie. W ten sposób bogactwo Bożego miłosierdzia mieści się nie tylko w skutecznej pomocy, ale przede wszystkim w zdolności bycia bliźnim dla cierpiącego człowieka. Jest to program każdej wspólnoty, w której myślą przewodnią jest nieść twórcze miłosierdzie, tzn. mieć wyobraźnię miłosierdzia. Taka wizja jest podstawą dla ewangelizacji i wymaga przede wszystkim świadectwa ${ }^{26}$.

Podsumowując, warto podkreślić, że Chrystus nadaje sens miłosiernym czynom człowieka. On wskazuje kierunek pomocy cierpiącemu. Zarówno Chrystus, jak i współczesny świat wymaga twórczej inicjatywy człowieka, by bliźni żył sensownie, był wolny od uzależnień i samotności. Zrealizowanie takiego programu jest możliwe w środowisku, które staje się domem dla człowieka. W nim głoszone jest miłosierdzie.

\section{„Wyobraźnia miłosierdzia” u świadków}

W homilii wygłoszonej na Błoniach krakowskich w 2002 roku Jan Paweł II zwrócił uwagę na fundamenty dzieła miłosierdzia oraz na świadków miłosierdzia, co wyraził w beatyfikacjach. Problem ten ujął w kontekście encykliki i przemówień w Polsce, poczynając od przemówienia na Błoniach w Krakowie w roku $1979^{27}$.

Analizując to przemówienie trzeba podkreślić, że Ojciec Święty w pierwszej części ukazał tajemnicę miłosierdzia Bożego i tajemnicę nieprawości w kontekście krzyża i zmartwychwstania. W drugiej zaś części nawiązał do świadków miłosierdzia, których beatyfikował. W trzeciej ukazał dzieła wyobraźni miłosierdzia.

\section{BÓG BOGATY W MIŁOSIERDZIE I TAJEMNICA NIEPRAWOŚCI}

„Pełnia tej miłości objawiła się w ofierze krzyża”28. Ofiara krzyża i oddanie życia za człowieka jest bogactwem i ceną miłosierdzia. Taki jest wzór i cena miłosierdzia wobec braci. Dlatego ofiara krzyża i zmartwychwstania jest początkiem zbawienia człowieka i fundamentem miłości. W kontekście tego papież podkreśla, że ,wiek dwudziesty [...] naznaczony był w szczególny sposób

${ }^{26}$ Por. tamże, 50.

${ }^{27}$ „Podczas mojej pierwszej pielgrzymki do Ojczyzny w 1979 roku, tu na Błoniach mówiłem, że «gdy jesteśmy mocni Duchem Boga, jesteśmy także mocni wiarą w człowieka - wiarą, nadzieją i miłością: są one nierozerwalne i jesteśmy gotowi świadczyć sprawie człowieka wobec każdego, któremu ta sprawa prawdziwie leży na sercu». Dlatego prosiłem was, «abyście nigdy nie wzgardzili tą Miłością, która jest 'największa', która się wyraziła przez krzyż, a bez której życie ludzkie nie ma ani korzenia, ani sensu»” (Homilia Ojca Świętego Jana Pawta II, Błonia, Kraków, niedziela 18 sierpnia 2002).

${ }^{28}$ Tamże, 1.

${ }^{29}$ Tamże, 3. 
«misterium nieprawości»"29. To misterium nieprawości uderzyło szczególnie w życie ludzkie i rodzinę, aby Boga samego uczynić „«wielkim nieobecnym» W kulturze i społecznej świadomości narodów"30. Ta postawa niesie cywilizację śmierci, lęku i bezsensu. Dlatego papież mówi: „Nadszedł czas, aby orędzie o Bożym miłosierdziu wlało w ludzkie serca nadzieję i stało się zarzewiem nowej cywilizacji - cywilizacji miłości”31. Dlatego na te czasy Bóg dał siostrę Faustynę, której Jezus ukazuje się jako Ten, który pokonuje miłosierdziem nieprawość. My mamy włączyć się w to dzieło praktyką miłosierdzia.

\section{PRAKTYKA MIEOSIERDZIA POTRZEBUJE WYOBRAŹNI}

W swej wypowiedzi papież wyraźnie domaga się pełnienia dzieł miłosierdzia. Rozwijając myśl o wyobraźni miłosierdzia, Ojciec Święty wskazuje na niektóre obszary ubóstwa. Dla przykładu podkreśla potrzebę wrażliwości, ,aby dostrzec obok siebie brata, który wraz z utratą pracy, dachu nad głową, możliwości godnego utrzymania rodziny i wykształcenia dzieci doznaje poczucia opuszczenia, zagubienia i beznadziei"32. Natomiast ks. Wojciech Misztal podkreśla Jezusową miłość miłosierną ${ }^{33}$. Na pewno jest to zadanie naglące, wobec którego społeczeństwo jest bezradne. Dlatego papież wczuwa się w sytuację człowieka, który tak bardzo został opuszczony. Widzi w sposób jasny, ze wyobraźnia miłosierdzia to odkrycie zagubienia i beznadziei bliźniego i solidaryzowanie się z nim.

Jan Paweł II wzywa do wrażliwości na potrzeby duchowe człowieka. „Potrzeba «wyobraźni miłosierdzia», aby przyjść z pomocą dziecku zaniedbanemu duchowo i materialnie; aby nie odwracać się od chłopca czy dziewczyny, którzy zagubili się w świecie różnorakich uzależnień lub przestępstwa" ${ }^{34}$. Następną formą miłosierdzia jest troska o wychowanie dzieci i młodzieży. Zazwyczaj brak wychowania doprowadza do zaniedbań nie tylko duchowych, ale i materialnych. Zaniedbany nie widzi też sensu życia i czuje się zagubiony. Papież wyraźnie podkreśla, że zaniedbanie i zagubienie prowadzi do uzależnień. Młody człowiek zniewolony często wchodzi na drogę bezprawia i przestępstwa.

${ }^{30}$ Tamże.

${ }^{31}$ Tamże.

${ }^{32}$ Tamże, 8.

${ }^{33}$ W. MiszTal, Znaczenie Chrystusowej miłości miłosiernej dla duchowości chrześcijańskiej na podstawie świadectw nowotestamentalnych, „Sympozjum” 2(2003), s. 88: „Nowotestamentalne przesłanie o Chrystusowej miłości miłosiernej pozwala i zobowiązuje do pokonania uprzedzeń, jakie może budzić świadczenie i przyjmowanie miłości miłosiernej, do zastanawiania się nad jej istotą i wartością, do świadczenia i przyjmowania jej. Przez Pismo św. Chrystus nadal mówi, naucza, zobowiązuje, daje przykład miłości miłosiernej, w ten sposób nadal okazuje miłosierdzie, zbawia, jest w tym niestrudzony".

${ }^{34}$ Homilia Ojca Świętego Jana Pawła II, Błonia, Kraków, niedziela 18 sierpnia 2002, 8. 
Wobec tej sytuacji trzeba postawić pytanie, w jaki sposób naprawdę można i trzeba pomóc wszystkim potrzebującym. Trzeba „nieść radę, pocieszenie, duchowe i moralne wsparcie tym, którzy podejmują wewnętrzną walkę ze złem"35. Znamienne jest to, iż Ojciec Święty mówi o wsparciu dla tych, którzy chcą wyjść z uzależnień, o pocieszaniu i dawaniu rady właśnie takim, którzy mają dobrą wolę. Trzeba więc rozeznania prawdziwych potrzeb i odpowiedniego środowiska, które pomoże wyjść z zaniedbań, zagubienia i beznadziei. To jest program ewangeliczny i program dla narodu.

\section{ŚWIADKOWIE}

Podczas mszy świętej na Błoniach papież beatyfikował czterech Polaków, którzy byli świadkami miłosierdzia. „Bł. Zygmunt Szczęsny Feliński, arcybiskup warszawski w trudnym czasie niewoli narodowej, wytrwale wzywał do ofiarności na rzecz ubogich, do otwierania instytucji wychowawczych i zakładów dobroczynnych. Sam otworzył sierociniec..." ${ }^{36}$. Natomiast bł. Jan Beyzym zbudował szpital i niósł nadzieję trędowatym na Madagaska$\mathrm{rze}^{37}$. Posługę miłosierdzia w konfesjonale w sposób wyjątkowy niósł bł. Jan Balicki $^{38}$. Dzieła miłosierdzia skierowały bł. Sancję Janinę Szymkowiak do serafitek, gdzie oddała się całkowicie do dyspozycji Boga ${ }^{39}$.

Całe przemówienie papieża, które skupia uwagę na orędziu o miłosierdziu, jest programem duszpasterskim dla Kościoła w Polsce. Aby zrozumieć ten program, trzeba wejść w życie świętych i błogosławionych, którzy czynili miłosierdzie. „Nie można zapomnieć, że z tej tradycji wyrosło wielu świętych, błogosławionych - kapłanów, osób konsekrowanych i wiernych świeckich - którzy poświęcili swe życie posłudze miłosierdzia. Od biskupa Stanisława, Jadwigi Królowej, Jana Kantego, Piotra Skargi, aż do Brata Alberta, Anieli Salawy i kardynała Sapiehy, kolejne pokolenia wiernych mieszkańców tego miasta podejmowały dziedzictwo miłosierdzia. Dziś to dziedzictwo zostało przekazane w nasze ręce i nie może pójść w zapomnienie" ${ }^{40}$. Papież dołącza do tego grona świadków, mówiąc o bliskości i modlitwie za bezrobotnych, bezdomnych, starszych, samotnych i rodziny wielodzietne ${ }^{41}$.

Jan Paweł II nawiązuje do listu Novo millenio ineunte, w którym ukazał program skierowany do świata. Program powyższy ma stać się programem Kościoła w Polsce. „W obliczu współczesnych form ubóstwa, których, jak wiemy, nie

\footnotetext{
${ }^{35}$ Tamże.

${ }^{36}$ Tamże, 4.

${ }^{37}$ Por. tamże, 5.

${ }^{38}$ Por. tamże, 6.

${ }^{39}$ Por. tamże, 7.

${ }^{40}$ Tamże, 2.

${ }^{41}$ Por. tamże.
} 
brakuje w naszym kraju, potrzebna jest dziś - jak to określiłem w Liście Novo millenio ineunte - „wyobraźnia miłosierdzia” w duchu solidarności z bliźnimi, dzięki której pomoc będzie świadectwem braterskiej wspólnoty dóbr. Niech tej wyobraźni nie zabraknie mieszkańcom Krakowa i całej Ojczyzny. Niech wyznacza duszpasterski program Kościoła w Polsce. Niech orędzie o Bożym Miłosierdziu zawsze znajduje odbicie w dziełach miłosierdzia ludzi”42.

\section{Zakończenie}

Podsumowując, warto zwrócić uwagę na to, że Jan Paweł II ukazuje wyobraźnię miłosierdzia w dwóch wymiarach. Pierwszy to zauważenie głodnych, biednych, bez wykształcenia i opieki lekarskiej, bezdomnych, samotnych, opuszczonych starszych i chorych, społecznie zdegradowanych i dyskryminowanych. W tym wymiarze potrzebującym konieczna jest przede wszystkim pomoc materialna. Obok niej ważna jest twórcza i pełna współczucia obecność oraz braterska troska. Bóg, który jest pełen dobroci i wierności, w Chrystusie utożsamia się z cierpiącym bliźnim, aż do przyjęcia hańbiącej męki i oddania się całkowicie człowiekowi. Papież podkreśla, że człowiek XX wieku stał się nie tylko niewrażliwy na cierpienia człowieka, lecz wręcz zadający okrutne cierpienia i dlatego Boga uczynił wielkim nieobecnym, by sam żył tak, jakby Boga nie było.

Drugim wymiarem jest troska o zaniedbane dzieci i młodych, którzy wpadli w uzależnienia i przestępstwa, a także o tych, którzy stracili sens życia. Istnieje konieczność rozeznania sytuacji potrzebujących, postawienia diagnozy i podjęcia walki ze złem. Diagnoza papieża i ratowanie człowieka zawiera się w tym, aby nieść radę, pocieszenie, duchowe i moralne wsparcie tym, którzy podejmują walkę ze złem.

Maryja wraz ze świętymi są świadkami, jak nawiedzać będących w potrzebie i troszczyć się o nich. Wielu świętych tworzyło ośrodki, organizacje, stowarzyszenia, ruchy, by pomóc potrzebującym. Inspiracją dla wyobraźni miłosierdzia jest zawsze Chrystus, który pochyla się nad chorymi i cierpiącymi, przebacza, uzdrawia, obdarza bogactwem słowa, a w Eucharystii pociesza i karmi. Matka Boża i święci takiego Chrystusa zobaczyli i takiego ukazują swoim życiem - wzywając do miłosierdzia. 


\section{Zusammenfassung}

Die Grundlagen der „Einbildungskraft der Barmherzigkeit““ in der Lehre vom Heiligen Vater Johannes Paul II.

Bei der Zusammenfassung des obigen Artikels ist darauf hinzuweisen, dass Johannes Paul II. die schöpferische Barmherzigkeit in zwei Dimensionen aufzeigt. Die erste besteht in der Wahrnehmung der Hungrigen, Armen, derjenigen, die ohne Ausbildung und ärztliche Betreuung sind, der Obdachlosen, Einsamen, der verlassenen alten und kranken Menschen, der gesellschaftlich Erniedrigten und Diskriminierten. In dieser Dimension benötigen die Bedürftigen vor allem materielle Hilfe. Neben diesen Haltungen ist eine schöpferische Gegenwart voller Mitgefühl und eine brüderliche Sorge wichtig. Gott ist voller Güte und Treue und identifiziert sich in Christus mit dem leidenden Nächsten so sehr, dass er schmachvolles Leiden auf sich nimmt und sich dem Menschen ganz ausliefert. Der Papst unterstreicht, dass der Mensch des 20. Jahrhunderts nicht nur unempfindlich für das menschliche Leiden geworden ist, sondern sogar selbst schreckliches Leiden verursacht und dadurch Gott zum großen Abwesenden gemacht hat, um selbst so leben zu können, als ob es Gott nicht gäbe. Die zweite Dimension ist die Sorge um vernachlässigte Kinder und Jugendliche, die in Süchte und Kriminalität verfallen sind, und um die, die den Sinn des Lebens verloren haben. Es ist notwendig, die Situation der Bedürftigen zu erkennen, eine Diagnose zu stellen und den Kampf gegen das Böse aufzunehmen. Die Diagnose des Papstes und die Rettung des Menschen besteht darin, denen, die den Kampf gegen das Böse aufgenommen haben, Rat, Trost und geistliche und moralische Unterstützung zu geben.

Maria und die Heiligen sind Zeugen dafür, wie man Bedürftige aufsucht und sich um sie sorgt. Viele Heilige haben Zentren, Organisationen, Gesellschaften, Bewegungen geschaffen, um den Bedürftigen zu helfen. Der Antrieb für die schöpferische Barmherzigkeit ist immer Christus, der sich zu den Kranken und Leidenden niederbeugt, der vergibt, heilt, den Reichtum des Wortes schenkt und in der Eucharistie tröstet und nährt. Diesen Christus haben die Gottesmutter und die Heiligen gesehen und zeigen ihn mit ihrem Leben, indem sie zur Barmherzigkeit aufrufen. 


\title{
NOWOŚć!
}

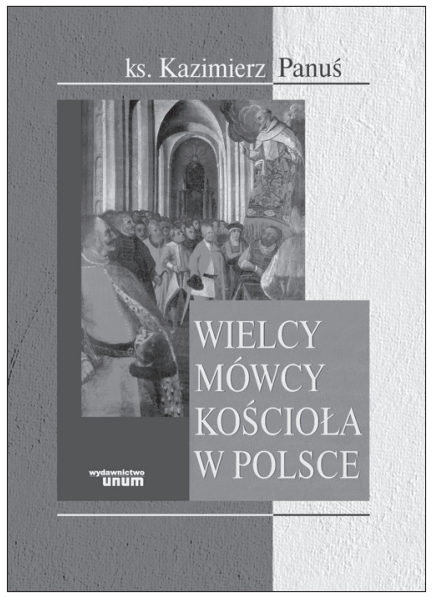

ks. Kazimierz Panuś

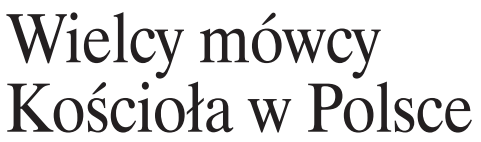

\author{
488 stron $\cdot$ format $16,5 \times 23,5 \mathrm{~mm}$ \\ oprawa twarda $\cdot$ cena 32 zł
}

Podejmując lekturę tej książki czytelnik zanurza się w fascynującą przygodę ukazującą stopniowe rozrastanie się ewangelii Chrystusowej i jej zakorzenianie na polskiej ziemi poprzez posługę głoszenia słowa Bożego. W uroczystym pochodzie przesuwają się sylwetki mistrzów polskiej ambony, poczynając od pierwszych kaznodziejskich dzieł Peregryna z Opola OP i ks. Stanisława ze Skarbimierza, poprzez wspaniały rozwój wymowy w XVI i XVII wieku, czego doskonałą ilustracją jest kaznodziejstwo ks. Stanisława Sokołowskiego, Piotra Skargi SI, Fabiana Birkowskiego OP, Tomasza Młodzianowskiego SI, Andrzeja Kochanowskiego OCD i Franciszka Rychłowskiego OFM, poprzez kaznodziejów XVIII- i XIXwiecznych takich, jak: Samuel Wysocki SchP, Sebastian Lachowski SI, bp Franciszek Karpowicz, abp Jan Paweł Woronicz, Karol Antoniewicz SI, Hieronim Kajsiewicz CR, św. bp Józef Sebastian Pelczar i ks. Władysław Chotkowski, aż po wielkich XX-wiecznych mistrzów polskiej ambony, wpierw z okresu międzywojennego, jak abp Antoni Szlagowski i abp Józef Teodorowicz, a potem z drugiej połowy XX wieku. W tej grupie spotkać można kapłanów takich, jak: Tadeusz Olszański CM, ks. Jan Zieja i ks. Julian Michalec oraz wielkich pasterzy narodu polskiego takich, jak: bp Jan Pietraszko, abp Jerzy Ablewicz, kard. Stefan Wyszyński, Prymas Tysiąclecia, a przede wszystkim kard. Karol Wojtyła Ojciec Święty Jan Paweł II. Wszyscy oni przynależą do panteonu narodowego kaznodziejstwa, a ich dokonania są klejnotami pierwszej wielkości w skarbnicy narodowej kultury. Oddając do rąk czytelnika niniejszy tom, autor żywi nadzieję, iż to spojrzenie na 25 wielkich mówców Kościoła w Polsce przyczyni się do głębszego zrozumienia istoty i roli kaznodziejstwa, do jego umiłowania i prowadzenia dalszych nad nim badań. Każde spotkanie z mistrzem polskiej ambony otwiera reprodukcja jego wizerunku lub ilustracja nawiązująca do jego osoby (herb zgromadzenia, kościół, w którym wygłaszał swoje kazania), a wieńczy przytoczony w całości charakterystyczny jego tekst kaznodziejski. Książka ta jest dobrą popularyzacją wiedzy o polskich kaznodziejach, a nie „ciężkim” dziełem naukowym, dlatego też najistotniejsze wskazówki bibliograficzne zamieszczono na końcu publikacji.

\section{Zamówienia}

Wydawnictwo UNUM · ul. Kanonicza 3 · 31-002 Kraków tel. (12) $4225690 \cdot$ e-mail: unum@ptt.net.pl Koszt przesyłki ponosi wydawnictwo. 